\title{
Conformational impact of structural modifications in 2-fluorocyclohexanone
}

\author{
Francisco A. Martins, Josué M. Silla and Matheus P. Freitas
}

\section{Full Research Paper}



Beilstein J. Org. Chem. 2017, 13, 1781-1787. doi:10.3762/bjoc. 13.172

Received: 19 June 2017

Accepted: 10 August 2017

Published: 24 August 2017

Associate Editor: J. A. Murphy

(c) 2017 Martins et al.; licensee Beilstein-Institut.

License and terms: see end of document.

\begin{abstract}
2-Haloketones are building blocks that combine physical, chemical and biological features of materials and bioactive compounds, while organic fluorine plays a fundamental role in the design of performance organic molecules. Since these features are dependent on the three-dimensional chemical structure of a molecule, simple structural modifications can affect its conformational stability and, consequently, the corresponding physicochemical/biological property of interest. In this work, structural changes in 2-fluorocyclohexanone were theoretically studied with the aim at finding intramolecular interactions that induce the conformational equilibrium towards the axial or equatorial conformer. The interactions evaluated were hydrogen bonding, hyperconjugation, electrostatic and steric effects. While the gauche effect, originated from hyperconjugative interactions, does not appear to cause some preferences for the axial conformation of organofluorine heterocycles, more classical effects indeed rule the conformational equilibrium of the compounds. Spectroscopic parameters (NMR chemical shifts and coupling constants), which can be useful to determine the stereochemistry and the interactions operating in the series of 2-fluorocyclohexanone derivatives, were also calculated.
\end{abstract}

\section{Introduction}

Organofluorine compounds are of special interest in materials, pharmaceutical and agricultural sciences, as the $\mathrm{C}-\mathrm{F}$ bond is the most polar bond in organic chemistry, which can be useful in the design of performance organic molecules [1]. A fluorine substituent in organofluorine compounds affects conformational properties, since it can induce stereoelectronic effects, such as $\sigma_{\mathrm{C}-\mathrm{H}}$ to $\sigma^{*} \mathrm{C}-\mathrm{F}$ hyperconjugative interactions in case of an antiparallel oriented $\mathrm{C}-\mathrm{H}$ bond. This is the origin of the so-called 'gauche effect', because electronegative $\mathrm{C}-\mathrm{X}$ bonds do not participate in such hyperconjugative interactions and therefore often give way to the $\mathrm{C}-\mathrm{H}$ bond in occupying the antiperiplanar orientation relative to the $\mathrm{C}-\mathrm{F}$ bond [2-6]. The electrostatic fluorine gauche effect has also been introduced in cases where the partially negative fluorine interacts with a positive nitrogen, such as in the 3-fluoropiperidinium cation [7-13].

The carbonyl group also plays a determinant role in the conformational isomerism of ketones and aldehydes [14-17]. Here the 
$\alpha$-carbonyl substituent can interact with the $\mathrm{C}=\mathrm{O}$ bond, either through a dipolar interaction with the carbonyl oxygen or by electron delocalization (hyperconjugation) involving the good electron acceptor $\pi^{*} \mathrm{C}=\mathrm{O}$ orbital. For example, 2-fluorocyclohexanone in the gas phase exists predominantly in the axial conformation, but the equatorial form is more stable in solution [18]. In a previous study [19], the introduction of an endocyclic oxygen in 2-fluorocyclohexanone to give the 3-fluorodihydro$2 \mathrm{H}$-pyran-4(3H)-one was expected to favor the axial orientation of the fluorine substituent because of the prospective gauche arrangement with the endocyclic oxygen, giving rise to the fluorine gauche effect, but this did not appear, because of a predominant $\sigma_{\mathrm{C}-\mathrm{H} 2} \rightarrow \pi^{*} \mathrm{C}=\mathrm{O}$ interaction in the equatorial conformer. The conformational induction through simple structural modifications can play an important role in the stereoselectivity of reactions (kinetically dependent on the conformation of the transition state) or in the ligand assessment to an enzyme binding site. Thus, the replacement of the endocyclic oxygen in 3-fluorodihydro-2H-pyran-4(3H)-one, as well as of the carbonyl oxygen, with other groups, can shift the conformational equilibrium of the resulting molecule towards the equatorial or the axial conformer. The axial conformer provides a gauche arrangement between the fluorine atom and the endocyclic group, while electron delocalization from electron donors, such as a $\sigma_{\mathrm{CH}}$ orbital to the vicinal $\pi^{*}$ orbital, as well as the spatial interaction between the fluorine substituent and the unsaturated bond, would also affect the conformational equilibrium.

The conformational equilibrium and other chemical/physical information for the compounds to be studied can be obtained using NMR parameters. For example, the long range ${ }^{4} J_{\mathrm{H}, \mathrm{H}}$ coupling constants passing through the carbonyl group in 2-bromocyclohexanone give insight on the coupling mechanism and is an experimental evidence for the hyperconjugation in this system [20]. In addition, the ${ }^{1} J_{\mathrm{C}, \mathrm{F}}$ coupling constant is a manifestation of the fluorine Perlin-like effect or its reversed analog, which can give information on the stereochemistry of organofluorine heterocycles [21-24].

Thus, this computational study has multi-focus objectives, namely exploring the effect of replacing the carbonyl oxygen and the methylene group at position 4 by other groups in order to induce conformational changes (relative to the fluorine orientation), as well as to evaluate the interactions controlling the conformational equilibriums and to obtain insight on the spectroscopic (NMR) behavior of the studied compounds (Figure 1).

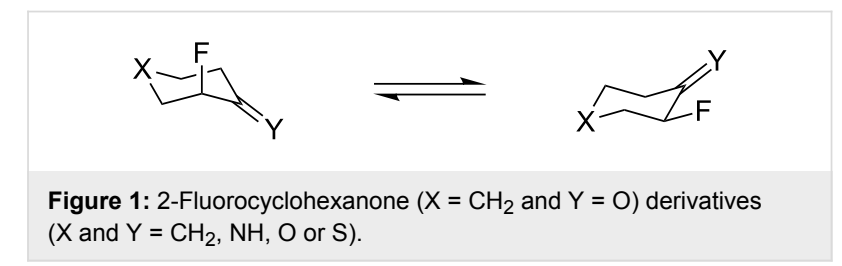

\section{Results and Discussion}

The axial population of 2-fluorocyclohexanone in the gas phase has been found to be $64 \%$, decreasing to only $2 \%$ in DMSO solution [18], which is in agreement with our theoretical findings (Table 1). This behavior is comprehensive, because the equatorial conformer has the $\mathrm{C}=\mathrm{O}$ and $\mathrm{C}-\mathrm{F}$ bonds in the same plane and similarly orientated. This should increase the molecular dipole moment, and favor the axial isomer. Because the two polar vectors are approximately at right angles, the electrostatic repulsion in the equatorial should be significantly relaxed in a high dielectric continuum.

Modifications of $\mathrm{X}$ and $\mathrm{Y}$ in the 2-fluorocyclohexanone framework of Figure 1 should cause conformational changes, as the intramolecular forces, as well as the solvent effect, are affected by the different groups $\left(\mathrm{CH}_{2}, \mathrm{NH}, \mathrm{O}\right.$ and $\left.\mathrm{S}\right)$ attached to these positions. Indeed, diverse conformational behaviors are ob-

\begin{tabular}{|c|c|c|c|c|c|}
\hline $\mathrm{Y} / \mathrm{X}$ & $\mathrm{X}=\mathrm{CH}_{2}$ & $x=0$ & $X=S$ & $\mathrm{X}=\mathrm{NH}_{\mathrm{ax}}$ & $\mathrm{X}=\mathrm{NH}_{\mathrm{eq}}$ \\
\hline $\mathrm{Y}=\mathrm{CH}_{2}$ & $\begin{array}{l}55 / 55 \\
(2.0 / 2.5)\end{array}$ & $\begin{array}{l}40 / 84 \\
(2.7 / 1.8)\end{array}$ & $\begin{array}{l}12 / 52 \\
(2.8 / 1.9)\end{array}$ & $\begin{array}{l}83 / 79 \\
(1.4 / 2.3)\end{array}$ & $\begin{array}{l}12 / 53 \\
(2.8 / 2.5)\end{array}$ \\
\hline$Y=O$ & $\begin{array}{l}65 / 5 \\
(3.1 / 4.9)\end{array}$ & $\begin{array}{l}42 / 14 \\
(2.0 / 3.3)\end{array}$ & $\begin{array}{l}21 / 4 \\
(1.5 / 3.2)\end{array}$ & $\begin{array}{l}88 / 11 \\
(2.1 / 4.4)\end{array}$ & $\begin{array}{l}15 / 4 \\
(3.6 / 4.7)\end{array}$ \\
\hline$Y=S$ & $\begin{array}{l}78 / 10 \\
(2.8 / 4.4)\end{array}$ & $\begin{array}{l}53 / 22 \\
(1.7 / 2.9)\end{array}$ & $\begin{array}{l}39 / 13 \\
(1.3 / 2.7)\end{array}$ & $\begin{array}{l}95 / 24 \\
(1.9 / 4.1)\end{array}$ & $\begin{array}{l}26 / 9 \\
(3.2 / 4.3)\end{array}$ \\
\hline $\mathrm{Y}=\mathrm{NH}_{Z}$ & $\begin{array}{l}3 / 3 \\
(2.5 / 3.4)\end{array}$ & $\begin{array}{l}2 / 10 \\
(1.9 / 1.7)\end{array}$ & $\begin{array}{l}0 / 2 \\
(1.7 / 1.6)\end{array}$ & $\begin{array}{l}10 / 9 \\
(1.4 / 3.0)\end{array}$ & $\begin{array}{l}0 / 3 \\
(3.1 / 3.3)\end{array}$ \\
\hline $\mathrm{Y}=\mathrm{NH}_{E}$ & $\begin{array}{l}98 / 52 \\
(3.0 / 4.6)\end{array}$ & $\begin{array}{l}95 / 72 \\
(2.7 / 3.6)\end{array}$ & $\begin{array}{l}89 / 54 \\
(2.4 / 3.5)\end{array}$ & $\begin{array}{l}100 / 71 \\
(2.2 / 4.3)\end{array}$ & $\begin{array}{l}81 / 44 \\
(3.5 / 4.5)\end{array}$ \\
\hline
\end{tabular}

aMolecular dipole moments for the axial/equatorial conformers in vacuum are given in parenthesis, second entries, in Debye. 
served when changing $X$ and $Y$ (Table 1). Nevertheless, it is worth noting that, in general, the axial population increases in DMSO solution relative to the gas phase only in compounds with $\mathrm{Y}=\mathrm{CH}_{2}$ (the population does not vary with the solvent when $\mathrm{X}=\mathrm{CH}_{2}$ and $\mathrm{NH}_{\mathrm{ax}}$ ). In these cases, the axial conformer has similar or larger molecular dipole moments than the equatorial form (differently from the other compounds). In addition, the $\pi^{*} \mathrm{C}=\mathrm{Y}$ orbitals $(\mathrm{Y}=\mathrm{O}, \mathrm{S}$ and $\mathrm{N})$ are better electron acceptors than the $\pi^{*} \mathrm{C}=\mathrm{C}$ in electron delocalization processes. These highlight the role of electrostatic and hyperconjugative effects on the conformational isomerism of the studied compounds.

Two particularly clear trends are related to the $\mathrm{NH}$ group at the $\mathrm{Y}$ position in vacuum: while the $\mathrm{NH}_{Z}$ leads to a strong shift toward the equatorial conformer for compounds with any $\mathrm{X}$, compounds with $\mathrm{NH}_{E}$ at the $\mathrm{Y}$ position strongly favor the axial conformer. It is intuitive that the equatorial conformer of compounds with $\mathrm{Y}=\mathrm{NH}_{Z}$ experience intramolecular hydrogen bond $\mathrm{F} \cdots \mathrm{HN}\left(\right.$ e.g., $d_{\mathrm{F} \cdots \mathrm{HN}}=2.21 \AA$ and $\mathrm{F} \cdots \mathrm{H}-\mathrm{N}$ angle $=110.0^{\circ}$, when $\mathrm{X} / \mathrm{Y}=\mathrm{CH}_{2} / \mathrm{NH}_{Z}$ ), despite similar interactions hardly ever appear in organofluorine compounds when forming 5-membered rings $[25,26]$. In addition, it is also quite intuitive that fluorine tends to occupy the axial orientation in compounds with $\mathrm{Y}=\mathrm{NH}_{E}$, as the nitrogen electron lone pair is directed toward the equatorial fluorine, thus causing electronic repulsion.

Other noticeable findings in the vacuum are those related to the compounds with endocyclic $\mathrm{CH}_{2}$ and $\mathrm{NH}_{\mathrm{ax}}$ groups (X). Most compounds in this series (except those with $\mathrm{NH}_{Z}$ as $\mathrm{Y}$, which exhibit intramolecular hydrogen bond with the equatorial fluorine) show axial prevalence. On the other hand, the equatorial conformer is preferred when $\mathrm{X}=\mathrm{S}$ and $\mathrm{NH}_{\mathrm{eq}}$ (except for $\mathrm{Y}=\mathrm{NH}_{E}$ ). While the axial preference for compounds with $\mathrm{X}=\mathrm{NH}_{\mathrm{ax}}$ can be determined by an electrostatic, dipolar relaxation $\mathrm{F} \cdots \mathrm{H}_{\mathrm{ax}} \mathrm{N}$ (since an intramolecular hydrogen bond has not been clearly demonstrated in 3-fluoropiperidine [7-13]), such behavior for compounds with $\mathrm{X}=\mathrm{CH}_{2}$ seems to be dependent on the $\mathrm{C}=\mathrm{Y}$ bond, since $\mathrm{X}=\mathrm{CH}_{2}$ is not a good proton donor. In this case, the axial population increases according to $\mathrm{Y}=\mathrm{CH}_{2}<\mathrm{O}<\mathrm{S}$, since the $\pi^{*} \mathrm{C}=\mathrm{C}$ is a bad electron-acceptor orbital in $\sigma_{\mathrm{C}-\mathrm{H} 2 \mathrm{ax}} \rightarrow \pi^{*} \mathrm{C}=\mathrm{Y}$ electron delocalizations and the classical steric/electrostatic repulsion of $\mathrm{O}$ and $\mathrm{S}$ with the equatorial fluorine is remarkable. This is corroborated by the Lewis and non-Lewis energies obtained by the natural orbital bond (NBO) decomposition analysis of Table 2 (which shows that the

\begin{tabular}{|c|c|c|c|c|}
\hline$x$ & $\mathrm{Y}$ & Total & Lewis & non-Lewis \\
\hline $\mathrm{CH}_{2}$ & $\mathrm{CH}_{2}$ & -0.1 & -3.7 & 3.6 \\
\hline $\mathrm{CH}_{2}$ & 0 & -0.5 & -10.4 & 9.9 \\
\hline $\mathrm{CH}_{2}$ & $\mathrm{~S}$ & -0.9 & -8.1 & 7.2 \\
\hline $\mathrm{CH}_{2}$ & $\mathrm{NH}_{Z}$ & 2.2 & -3.7 & 5.9 \\
\hline $\mathrm{CH}_{2}$ & $\mathrm{NH}_{E}$ & -2.5 & -10.1 & 7.6 \\
\hline $\mathrm{O}$ & $\mathrm{CH}_{2}$ & 0.3 & 1.5 & -1.2 \\
\hline $\mathrm{O}$ & 0 & 0.2 & -4.7 & 4.9 \\
\hline $\mathrm{O}$ & $S$ & -0.1 & -2.9 & 2.9 \\
\hline $\mathrm{O}$ & $\mathrm{NH}_{Z}$ & 2.7 & 1.9 & 0.8 \\
\hline $\mathrm{O}$ & $\mathrm{NH}_{E}$ & -1.8 & -4.8 & 2.9 \\
\hline S & $\mathrm{CH}_{2}$ & 1.5 & 1.7 & -0.2 \\
\hline $\mathrm{S}$ & $\mathrm{O}$ & 0.9 & -4.8 & 5.7 \\
\hline$S$ & $S$ & 0.3 & -2.4 & 2.7 \\
\hline$S$ & $\mathrm{NH}_{Z}$ & 3.8 & 1.7 & 2.1 \\
\hline $\mathrm{S}$ & $\mathrm{NH}_{E}$ & -1.1 & -4.8 & 3.7 \\
\hline $\mathrm{NH}_{\mathrm{ax}}$ & $\mathrm{CH}_{2}$ & -1.1 & -3.8 & 2.7 \\
\hline $\mathrm{NH}_{\mathrm{ax}}$ & 0 & -1.4 & -10.1 & 8.6 \\
\hline $\mathrm{NH}_{\mathrm{ax}}$ & $S$ & -1.9 & -7.5 & 5.7 \\
\hline $\mathrm{NH}_{\mathrm{ax}}$ & $\mathrm{NH}_{Z}$ & 1.2 & -3.7 & 4.9 \\
\hline $\mathrm{NH}_{\mathrm{ax}}$ & $\mathrm{NH}_{E}$ & -3.3 & -10.1 & 6.8 \\
\hline $\mathrm{NH}_{\mathrm{eq}}$ & $\mathrm{CH}_{2}$ & 1.3 & 2.4 & -1.1 \\
\hline $\mathrm{NH}_{\mathrm{eq}}$ & $\mathrm{O}$ & 1.2 & -3.5 & 4.7 \\
\hline $\mathrm{NH}_{\mathrm{eq}}$ & $S$ & 0.7 & -1.8 & 2.5 \\
\hline $\mathrm{NH}_{\mathrm{eq}}$ & $\mathrm{NH}_{Z}$ & 3.7 & 2.5 & 1.2 \\
\hline $\mathrm{NH}_{\mathrm{eq}}$ & $\mathrm{NH}_{E}$ & -1.0 & -3.9 & 2.9 \\
\hline
\end{tabular}


axial conformer is less favored by the Lewis term in $\mathrm{Y}=\mathrm{S}$ than $\mathrm{O}$ ), and also by the relatively low value for the $\sigma_{\mathrm{C}-\mathrm{H} 2 \mathrm{ax}} \rightarrow \pi^{*}{ }_{\mathrm{C}=\mathrm{C}}$ interaction given in Table 3 . It is worth mentioning that the $\sigma_{\mathrm{C}-\mathrm{H} 2 \mathrm{ax}} \rightarrow \pi^{*} \mathrm{C}=\mathrm{O}$ and $\sigma_{\mathrm{C}-\mathrm{H} 2 \mathrm{ax}} \rightarrow \pi^{*} \mathrm{C}=\mathrm{S}$ interactions are more stabilizing than $\sigma_{\mathrm{C}-\mathrm{H} 2 \mathrm{ax}} \rightarrow \pi^{*} \mathrm{C}=\mathrm{C}$, but they are also accompanied by strong steric and electrostatic interactions (see the high values for both Lewis and non-Lewis terms when $\mathrm{Y}=\mathrm{O}$ and $\mathrm{S}$ compared to $\mathrm{CH}_{2}$ ). When the $\mathrm{X}=\mathrm{S}$ and $\mathrm{NH}_{\mathrm{eq}}$ groups take place, the equatorial conformer predominates, as an axial hydrogen at $\mathrm{X}$ (either from the $\mathrm{CH}_{2}$ or $\mathrm{NH}_{\mathrm{ax}}$ ) is replaced by an electron lone pair (LP), giving rise to $\mathrm{F}_{\mathrm{ax}} \ldots \mathrm{LP}_{\mathrm{X}}$ repulsion.

For compounds with $\mathrm{X}$ other than the NH group (which exhibit specific interactions), the axial population increases according to $\mathrm{X}=\mathrm{S}<\mathrm{O}<\mathrm{CH}_{2}$, as a clear effect of size and/or electronegativity rather than hyperconjugation, thus revealing the steric and/or electrostatic nature of the interactions between the gauche $\mathrm{X}$ and $\mathrm{F}_{\mathrm{ax}}$ groups. The opposite effect is observed for $\mathrm{Y}=\mathrm{S}, \mathrm{O}$ and $\mathrm{CH}_{2}$, i.e., the axial population increases according to $\mathrm{Y}=\mathrm{CH}_{2}<\mathrm{O}<\mathrm{S}$, since the repulsion with the $\mathrm{F}_{\text {eq }}$ substituent increases in this order. The hypothesis based on steric and electrostatic interactions is supported by the increase of the axial population from $\mathrm{Y}=\mathrm{CH}_{2}$ to $\mathrm{S}$, despite the better electron-acceptor ability of the $\pi^{*} \mathrm{C}=\mathrm{S}$ in comparison to $\pi^{*} \mathrm{C}=\mathrm{O}$ and $\pi^{*} \mathrm{C}=\mathrm{C}$, e.g., in the $\sigma_{\mathrm{C}-\mathrm{Hax}} \rightarrow \pi^{*} \mathrm{C}=\mathrm{Y}$ interactions for the equatorial conformer (see NBO electron delocalization energies of Table 3).

The gauche effect does not appear to be induced by hyperconjugation involving the endocyclic $\mathrm{X}$, even when $\mathrm{X}=\mathrm{O}$, such as in most cases where this phenomenon is observed. Differently from acyclic organofluorine compounds, hyperconjugation is not sufficiently effective in organofluorine heterocycles because they do not have enough antiperiplanar $\mathrm{C}-\mathrm{H}$ bonds as electron donors to participate in $\sigma_{\mathrm{C}-\mathrm{H}} \rightarrow \sigma^{*} \mathrm{C}-\mathrm{F}$ and $\sigma_{\mathrm{C}-\mathrm{H}} \rightarrow \sigma^{*} \mathrm{C}-\mathrm{X}$ electron-delocalization processes. Intramolecular hydrogen bonding, when possible, is a better source of stabilization, but the interaction of $\mathrm{F}$ with $\mathrm{Y}$ (or the $\mathrm{C}=\mathrm{Y}$ bond) appears to be more relevant as the controlling effect of the conformational isomerism of the studied compounds. Thus, classical effects explain satisfactorily the conformational behavior of the studied compounds, according to the NBO analysis and in spite of some stabilizing electronic delocalization interactions from electron-donor orbitals to antiperiplanar antibonding orbitals.

\begin{tabular}{|c|c|c|c|c|c|}
\hline$x$ & Y & $\sigma_{\mathrm{C}-\mathrm{H} 3} \rightarrow \sigma^{*} \mathrm{C}-\mathrm{F}$ & $\sigma_{\mathrm{C}-\mathrm{F}} \rightarrow \sigma^{*} \mathrm{C}-\mathrm{H} 3$ & $\sigma_{\mathrm{C}-\mathrm{H} 3} \rightarrow \sigma^{*} \mathrm{C}-\mathrm{X}$ & $\sigma_{\mathrm{C}-\mathrm{X}} \rightarrow \sigma^{*} \mathrm{C}-\mathrm{H} 3$ \\
\hline $\mathrm{CH}_{2}$ & $\mathrm{CH}_{2}$ & $6.3 /-$ & $1.2 /-$ & $3.3 /-$ & $2.0 /-$ \\
\hline $\mathrm{CH}_{2}$ & 0 & 6.3/- & $1.1 /-$ & $3.1 /-$ & $2.0 /-$ \\
\hline $\mathrm{CH}_{2}$ & $S$ & $6.2 /-$ & $1.1 /-$ & $3.1 /-$ & $2.0 /-$ \\
\hline $\mathrm{CH}_{2}$ & $\mathrm{NH}_{Z}$ & $6.4 /-$ & $1.1 /-$ & $3.1 /-$ & $2.0 /-$ \\
\hline $\mathrm{CH}_{2}$ & $\mathrm{NH}_{E}$ & $6.3 /-$ & $1.2 /-$ & $3.2 /-$ & $2.0 /-$ \\
\hline $\mathrm{O}$ & $\mathrm{CH}_{2}$ & $5.8 /-$ & $1.0 /-$ & $4.4 /-$ & $0.9 /-$ \\
\hline $\mathrm{O}$ & $\mathrm{O}$ & $5.7 /-$ & $1.0 /-$ & $4.2 /-$ & $0.9 /-$ \\
\hline $\mathrm{O}$ & $S$ & $5.5 /-$ & $1.0 /-$ & $4.4 /-$ & $0.9 /-$ \\
\hline $\mathrm{O}$ & $\mathrm{NH}_{Z}$ & $5.9 /-$ & $0.9 /-$ & $4.3 /-$ & $0.9 /-$ \\
\hline $\mathrm{O}$ & $\mathrm{NH}_{E}$ & $5.7 /-$ & $1.1 /-$ & $4.4 /-$ & $0.9 /-$ \\
\hline S & $\mathrm{CH}_{2}$ & $6.0 /-$ & $1.0 /-$ & $5.8 /-$ & $2.3 /-$ \\
\hline S & O & $5.9 /-$ & $1.0 /-$ & $5.4 /-$ & $2.3 /-$ \\
\hline$S$ & $S$ & $5.8 /-$ & $0.9 /-$ & $5.4 /-$ & $2.3 /-$ \\
\hline S & $\mathrm{NH}_{z}$ & $6.0 /-$ & $0.9 /-$ & $5.6 /-$ & $2.4 /-$ \\
\hline S & $\mathrm{NH}_{E}$ & $6.0 /-$ & $1.0 /-$ & $5.8 /-$ & $2.3 /-$ \\
\hline $\mathrm{NH}_{\mathrm{ax}}$ & $\mathrm{CH}_{2}$ & $5.8 /-$ & $1.1 /-$ & $4.0 /-$ & $1.2 /-$ \\
\hline $\mathrm{NH}_{\mathrm{ax}}$ & $\mathrm{O}$ & $5.6 /-$ & $1.1 /-$ & $3.7 /-$ & $1.2 /-$ \\
\hline $\mathrm{NH}_{\mathrm{ax}}$ & $S$ & $5.4 /-$ & $1.0 /-$ & $3.6 /-$ & $1.1 /-$ \\
\hline $\mathrm{NH}_{\mathrm{ax}}$ & $\mathrm{NH}_{Z}$ & 5.9/- & $1.0 /-$ & $3.8 /-$ & $1.2 /-$ \\
\hline $\mathrm{NH}_{\mathrm{ax}}$ & $\mathrm{NH}_{E}$ & $5.8 /-$ & $1.1 /-$ & $3.8 /-$ & $1.2 /-$ \\
\hline $\mathrm{NH}_{\mathrm{eq}}$ & $\mathrm{CH}_{2}$ & $6.1 /-$ & $1.0 /-$ & $3.7 /-$ & $1.2 /-$ \\
\hline $\mathrm{NH}_{\mathrm{eq}}$ & 0 & $6.1 /-$ & $1.0 /-$ & $3.5 /-$ & $1.2 /-$ \\
\hline $\mathrm{NH}_{\mathrm{eq}}$ & $S$ & 5.9/- & $1.0 /-$ & $3.5 /-$ & $1.2 /-$ \\
\hline $\mathrm{NH}_{\mathrm{eq}}$ & $\mathrm{NH}_{Z}$ & $6.2 /-$ & $1.0 /-$ & $3.5 /-$ & $1.3 /-$ \\
\hline $\mathrm{NH}_{\mathrm{eq}}$ & $\mathrm{NH}_{E}$ & $6.1 /-$ & $1.0 /-$ & $3.6 /-$ & $1.2 /-$ \\
\hline
\end{tabular}




\begin{tabular}{|c|c|c|c|c|c|}
\hline$x$ & Y & $\sigma_{\mathrm{C}-\mathrm{X}} \rightarrow \sigma^{*}{ }_{\mathrm{C}-\mathrm{F}}$ & $\sigma_{\mathrm{C}-\mathrm{F}} \rightarrow \sigma^{*}{ }_{\mathrm{C}-\mathrm{X}}$ & $\sigma_{\mathrm{C}-\mathrm{H} 2} \rightarrow \pi^{*} \mathrm{C}=\mathrm{Y}$ & $\sigma_{\mathrm{C} 1-\mathrm{C} 2} \rightarrow \sigma^{*}{ }_{C-x^{a}}^{a}$ \\
\hline $\mathrm{CH}_{2}$ & $\mathrm{CH}_{2}$ & $-/ 3.8$ & $-/ 1.1$ & $-/ 6.2$ & $-1-$ \\
\hline $\mathrm{CH}_{2}$ & $\mathrm{O}$ & $-/ 3.7$ & $-/ 1.1$ & $-/ 7.2$ & $-1-$ \\
\hline $\mathrm{CH}_{2}$ & $S$ & $-/ 3.5$ & $-/ 1.1$ & $-/ 8.5$ & $-1-$ \\
\hline $\mathrm{CH}_{2}$ & $\mathrm{NH}_{Z}$ & -14.0 & $-/ 1.1$ & $-/ 6.5$ & $-1-$ \\
\hline $\mathrm{CH}_{2}$ & $\mathrm{NH}_{E}$ & $-/ 3.6$ & $-/ 1.1$ & $-/ 6.5$ & $-1-$ \\
\hline $\mathrm{O}$ & $\mathrm{CH}_{2}$ & $-/ 2.0$ & $-/ 1.4$ & $-/ 6.2$ & $-1-$ \\
\hline $\mathrm{O}$ & O & $-/ 1.8$ & $-/ 1.3$ & $-/ 7.4$ & $0.6 /-$ \\
\hline $\mathrm{O}$ & $S$ & $-/ 1.7$ & $-/ 1.3$ & $-/ 8.6$ & $-1-$ \\
\hline $\mathrm{O}$ & $\mathrm{NH}_{Z}$ & $-/ 2.0$ & $-/ 1.3$ & $-/ 6.6$ & $-1-$ \\
\hline $\mathrm{O}$ & $\mathrm{NH}_{E}$ & $-/ 1.8$ & $-/ 1.4$ & $-/ 6.7$ & $0.5 /-$ \\
\hline$S$ & $\mathrm{CH}_{2}$ & $-/ 4.5$ & $-/ 1.8$ & $-/ 5.5$ & $-1-$ \\
\hline$S$ & $\mathrm{O}$ & $-/ 4.3$ & $-/ 1.7$ & -16.5 & $-1-$ \\
\hline$S$ & $S$ & $-/ 4.1$ & $-/ 1.7$ & $-/ 7.3$ & $-1-$ \\
\hline$S$ & $\mathrm{NH}_{Z}$ & -14.7 & $-/ 1.7$ & $-/ 5.9$ & $-1-$ \\
\hline$S$ & $\mathrm{NH}_{E}$ & -14.2 & $-/ 1.8$ & $-/ 5.8$ & $-1-$ \\
\hline $\mathrm{NH}_{\mathrm{ax}}$ & $\mathrm{CH}_{2}$ & $-/ 2.3$ & $-/ 1.3$ & $-/ 6.2$ & $-1-$ \\
\hline $\mathrm{NH}_{\mathrm{ax}}$ & $\mathrm{O}$ & $-/ 2.1$ & $-/ 1.3$ & $-/ 7.2$ & $-1-$ \\
\hline $\mathrm{NH}_{\mathrm{ax}}$ & $S$ & $-/ 2.0$ & $-/ 1.3$ & $-/ 8.4$ & $-1-$ \\
\hline $\mathrm{NH}_{\mathrm{ax}}$ & $\mathrm{NH}_{Z}$ & $-/ 2.4$ & $-/ 1.3$ & $-/ 6.5$ & $-1-$ \\
\hline $\mathrm{NH}_{\mathrm{ax}}$ & $\mathrm{NH}_{E}$ & $-/ 2.1$ & $-/ 1.3$ & $-/ 6.5$ & $-1-$ \\
\hline $\mathrm{NH}_{\mathrm{eq}}$ & $\mathrm{CH}_{2}$ & $-/ 2.7$ & $-/ 1.2$ & $-/ 6.1$ & $-1-$ \\
\hline $\mathrm{NH}_{\mathrm{eq}}$ & 0 & $-/ 2.6$ & $-/ 1.1$ & $-/ 7.4$ & $-1-$ \\
\hline $\mathrm{NH}_{\text {eq }}$ & $S$ & $-/ 2.4$ & $-/ 1.1$ & $-/ 8.5$ & $-1-$ \\
\hline $\mathrm{NH}_{\text {eq }}$ & $\mathrm{NH}_{Z}$ & $-/ 2.8$ & $-/ 1.1$ & $-/ 6.5$ & $-1-$ \\
\hline $\mathrm{NH}_{\text {eq }}$ & $\mathrm{NH}_{E}$ & $-/ 2.5$ & $-/ 1.2$ & $-/ 6.6$ & $-1-$ \\
\hline
\end{tabular}

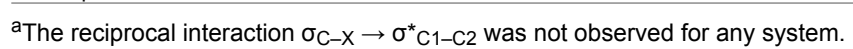

The electronic interactions mentioned above appeared to be sensitive to the solvent effect, since the population of the equatorial conformer increased with the solvent polarity, as dipolar repulsion between $\mathrm{Y}$ and $\mathrm{F}$ decreases in solvents with increasing dielectric constants.

Nuclear magnetic resonance (NMR) parameters, namely chemical shifts and coupling constants, can be useful to provide information on conformational population and intramolecular interactions. The ${ }^{3} J_{\mathrm{H}, \mathrm{H}}$ coupling constant has been widely used to estimate conformers population in an equilibrium [18], because of its dependence with the $\mathrm{H}-\mathrm{C}-\mathrm{C}-\mathrm{H}$ dihedral angle, according to the Karplus curve. Chemical shifts can also be used, but they are more sensitive to solvent changes [27]. In the present study, the calculated H-1 and F-19 chemical shifts (Table 4) are too close for both conformers to differentiate them by comparing the absolute (calculated) and the mean experimental values. Also, the calculated long-range coupling constants ${ }^{4} J_{\mathrm{H}, \mathrm{H}}$ are too small to infer something about any coupling pathway involving hyperconjugative interaction via the $\mathrm{C}=\mathrm{Y}$ bond, as in 2-bromocyclohexanone [20]. However, the ${ }^{1} J_{\mathrm{C}, \mathrm{F}}$ coupling constant varies significantly from one conformer to the other, which can give insight either into conformer populations or intramolecular interactions operating in these systems. Since most $\left|{ }^{1} J_{\mathrm{C}, \mathrm{F}}\right|$ values in Table 4 are larger for the equatorial conformer (except for the compound with $\mathrm{X}=\mathrm{NH}_{\mathrm{eq}}$ and $\mathrm{Y}=\mathrm{NH}_{Z}$ ), the fluorine Perlin-like effect takes place. The literature [21-24] has attributed such effect to the interaction between the fluorine atom (or the $\mathrm{C}-\mathrm{F}$ bond) and the $\mathrm{Y}$ group (or the $\mathrm{C}=\mathrm{Y}$ bond), which has been well described by a spatial/ dipolar interaction between these groups, despite a minor contribution from hyperconjugation. Thus, the fluorine Perlinlike effect shown in Table 4 supports our conclusions that classical effects govern the conformational equilibrium of the studied series of compounds.

\section{Conclusion}

Hyperconjugation plays a secondary role as dictating interaction of the conformational isomerism of 2-fluorocyclohexanone derivatives investigated in this study. The more classical steric and electrostatic effects (and hydrogen bonding, when possible) should be invoked as the main interactions governing the conformational equilibrium of these compounds. The gauche effect does not appear to be due to hyperconjugation, despite 
Table 4: Calculated NMR parameters $\left(J\right.$ in $\mathrm{Hz}$ and $\delta$ in ppm, relative to TMS for ${ }^{1} \mathrm{H}$ and TFA for $\left.{ }^{19} \mathrm{~F}\right)$ in vacuum.

\begin{tabular}{|c|c|c|c|c|c|c|c|c|c|c|c|}
\hline$x$ & $Y$ & ${ }^{1} J_{C, \text { Fax }}$ & ${ }^{1} J_{C, \text { Feq }}$ & ${ }^{4} J_{\mathrm{H} 2 \mathrm{eq}, \mathrm{H} 6 \mathrm{eq}}$ & ${ }^{4} J_{H 2 e q, H 6 a x}$ & ${ }^{4} J_{\mathrm{H} 2 \mathrm{ax}, \mathrm{H} 6 \mathrm{eq}}$ & ${ }^{4} J_{\mathrm{H} 2 \mathrm{ax}, \mathrm{H} 6 \mathrm{ax}}$ & $\delta_{\mathrm{H} 2 \mathrm{ax}}$ & $\delta_{\mathrm{H} 2 \mathrm{eq}}$ & $\delta_{\mathrm{Fax}}$ & $\delta_{\mathrm{Feq}}$ \\
\hline $\mathrm{CH}_{2}$ & $\mathrm{CH}_{2}$ & -171.2 & -192.2 & 0.3 & -0.7 & -0.6 & -0.7 & 4.8 & 4.8 & -111.1 & -119.2 \\
\hline $\mathrm{CH}_{2}$ & $\mathrm{O}$ & -181.8 & -205.0 & 0.6 & -0.5 & -0.4 & 1.4 & 4.4 & 4.7 & -123.0 & -127.0 \\
\hline $\mathrm{CH}_{2}$ & $S$ & -184.5 & -200.8 & 0.4 & -0.7 & -0.4 & 0.0 & 5.0 & 5.3 & -103.9 & -101.9 \\
\hline $\mathrm{CH}_{2}$ & $\mathrm{NH}_{Z}$ & -181.0 & -189.3 & 0.6 & -0.6 & -0.5 & 0.1 & 4.3 & 4.7 & -114.2 & -125.9 \\
\hline $\mathrm{CH}_{2}$ & $\mathrm{NH}_{E}$ & -173.1 & -204.7 & 0.5 & -0.6 & -0.4 & 0.2 & 4.9 & 4.7 & -121.5 & -123.6 \\
\hline O & $\mathrm{CH}_{2}$ & -180.3 & -194.6 & 0.4 & -0.7 & -0.7 & -0.9 & 4.5 & 4.9 & -113.7 & -138.3 \\
\hline $\mathrm{O}$ & $\mathrm{O}$ & -189.6 & -207.2 & 0.7 & -0.5 & -0.5 & 1.3 & 4.2 & 4.8 & -126.8 & -144.0 \\
\hline O & $S$ & -192.5 & -203.2 & 0.6 & -0.6 & -0.5 & -0.3 & 4.8 & 5.3 & -107.6 & -120.3 \\
\hline O & $\mathrm{NH}_{Z}$ & -189.3 & -192.2 & 0.7 & -0.6 & -0.6 & 0.0 & 4.0 & 4.7 & -118.2 & -144.1 \\
\hline O & $\mathrm{NH}_{E}$ & -181.7 & -206.6 & 0.7 & -0.6 & -0.5 & 0.1 & 4.6 & 4.8 & -124.7 & -142.1 \\
\hline S & $\mathrm{CH}_{2}$ & -181.7 & -195.8 & 0.1 & -0.7 & -0.5 & -0.6 & 4.8 & 4.9 & -110.4 & -110.1 \\
\hline S & 0 & -192.8 & -209.2 & 0.4 & -0.4 & -0.3 & 1.2 & 4.4 & 4.8 & -122.0 & -118.2 \\
\hline S & $S$ & -195.3 & -204.6 & 0.2 & -0.7 & -0.4 & -0.1 & 5.1 & 5.4 & -102.7 & -93.1 \\
\hline$S$ & $\mathrm{NH}_{Z}$ & -191.8 & -193.0 & 0.4 & -0.5 & -0.4 & 0.1 & 4.4 & 4.8 & -113.5 & -117.4 \\
\hline$S$ & $\mathrm{NH}_{E}$ & -183.7 & -208.7 & 0.3 & -0.5 & -0.4 & 0.2 & 4.9 & 4.9 & -120.7 & -114.6 \\
\hline $\mathrm{NH}_{\mathrm{ax}}$ & $\mathrm{CH}_{2}$ & -169.6 & -199.9 & 0.2 & -0.7 & -0.6 & -0.7 & 4.5 & 4.6 & -116.1 & -128.7 \\
\hline $\mathrm{NH}_{\mathrm{ax}}$ & 0 & -179.4 & -212.5 & 0.5 & -0.5 & -0.4 & 1.4 & 4.3 & 4.5 & -126.9 & -135.3 \\
\hline $\mathrm{NH}_{\mathrm{ax}}$ & $S$ & -182.8 & -208.2 & 0.4 & -0.7 & -0.5 & 0.0 & 4.9 & 5.1 & -106.8 & -110.7 \\
\hline $\mathrm{NH}_{\mathrm{ax}}$ & $\mathrm{NH}_{Z}$ & -179.0 & -197.4 & 0.5 & -0.6 & -0.5 & 0.1 & 4.1 & 4.5 & -119.0 & -135.3 \\
\hline $\mathrm{NH}_{\mathrm{ax}}$ & $\mathrm{NH}_{E}$ & -170.8 & -211.8 & 0.4 & -0.6 & -0.5 & 0.2 & 4.7 & 4.5 & -126.2 & -132.9 \\
\hline $\mathrm{NH}_{\mathrm{eq}}$ & $\mathrm{CH}_{2}$ & -181.8 & -190.2 & 0.5 & -0.7 & -0.6 & -0.9 & 4.6 & 4.9 & -112.0 & -130.8 \\
\hline $\mathrm{NH}_{\mathrm{eq}}$ & 0 & -191.5 & -202.9 & 0.8 & -0.5 & -0.5 & 0.1 & 4.2 & 4.8 & -125.5 & -137.4 \\
\hline $\mathrm{NH}_{\text {eq }}$ & $S$ & -194.1 & -198.9 & 0.6 & -0.6 & -0.5 & -0.4 & 4.8 & 5.4 & -106.2 & -113.6 \\
\hline $\mathrm{NH}_{\text {eq }}$ & $\mathrm{NH}_{Z}$ & -191.0 & -187.6 & 0.8 & -0.6 & -0.6 & -0.1 & 4.2 & 4.8 & -116.5 & -137.1 \\
\hline $\mathrm{NH}_{\mathrm{eq}}$ & $\mathrm{NH}_{E}$ & -183.2 & -202.5 & 0.7 & -0.6 & -0.5 & 0.0 & 4.7 & 4.8 & -123.3 & -134.8 \\
\hline
\end{tabular}

some preferences for the axial conformation (in which the fluorine atom has a gauche arrangement relative to $\mathrm{X})$, because of a lack of stabilizing $\sigma_{\mathrm{C}-\mathrm{H}} \rightarrow \sigma^{*} \mathrm{C}-\mathrm{F}$ and $\sigma_{\mathrm{C}-\mathrm{H}} \rightarrow \sigma^{*} \mathrm{C}-\mathrm{X}$ interactions. The fluorine Perlin-like effect observed for calculated ${ }^{1} J_{\mathrm{C}, \mathrm{F}}$ coupling constants confirms these findings.

\section{Computational Methods}

Optimization and frequency calculations were performed at the $\omega B 97 X-D / 6-311++g(d, p)[28,29]$ level (thus including empirical dispersion effects) to obtain the Gibbs free energies (1.00 atm and 298.15 K). Natural orbital bond (NBO) analyses were carried out for the optimized structures at the same level of theory using the NBO 6.0 program [30], in order to obtain the electronic delocalization energies, as well as the Lewis (steric and electrostatic interactions) and non-Lewis (electron delocalization) contributions through the NOSTAR keyword. Chemical shifts and spin-spin coupling constant calculations were also performed at the $\omega$ B97X-D/6-311+g(d,p) level. All the calculations were processed using the Gaussian 09 program [31] for the gas phase and implicit DMSO (using the polarizable continuum model [32]).

\section{Supporting Information}

\section{Supporting Information File 1}

Computational data.

[http://www.beilstein-journals.org/bjoc/content/

supplementary/1860-5397-13-172-S1.pdf]

\section{Acknowledgements}

The authors are thankful to CNPq, CAPES and FAPEMIG for the financial support of this research, as well as for the scholarship (to F.A.M.) and fellowships (to J.M.S. and M.P.F.).

\section{References}

1. O'Hagan, D. J. Org. Chem. 2012, 77, 3689-3699. doi:10.1021/jo300044q

2. Zefirov, N. S.; Samoshin, V. V.; Subbotin, O. A.; Baranenkov, V. I.; Wolfe, S. Tetrahedron 1978, 34, 2953-2959. doi:10.1016/0040-4020(78)88017-X

3. Rablen, P. R.; Hoffmann, R. W.; Hrovat, D. A.; Borden, W. T. J. Chem. Soc., Perkin Trans. 2 1999, 1719-1726. doi:10.1039/A901974J 
4. Goodman, L.; Gu, H.; Pophristic, V. J. Phys. Chem. A 2005, 109, 1223-1229. doi:10.1021/jp046290d

5. Buissonneaud, D. Y.; van Mourik, T.; O'Hagan, D. Tetrahedron 2010, 66, 2196-2202. doi:10.1016/j.tet.2010.01.049

6. Thiehoff, C.; Rey, Y. P.; Gilmour, R. Isr. J. Chem. 2017, 57, 92-100. doi:10.1002/ijch.201600038

7. Lankin, D. C.; Grunewald, G. L.; Romero, F. A.; Oren, I. Y.; Snyder, J. P. Org. Lett. 2002, 4, 3557-3560. doi:10.1021/ol026358c

8. Snyder, J. P.; Chandrakumar, N. S.; Sato, H.; Lankin, D. C. J. Am. Chem. Soc. 2000, 122, 544-545. doi:10.1021/ja9934504

9. Lankin, D. C.; Chandrakumar, N. S.; Rao, S. N.; Spangler, D. P.; Snyder, J. P. J. Am. Chem. Soc. 1993, 115, 3356-3357. doi:10.1021/ja00061a055

10. Sun, A.; Lankin, D. C.; Hardcastle, K.; Snyder, J. P. Chem. - Eur. J. 2005, 11, 1579-1591. doi:10.1002/chem.200400835

11. Gooseman, N. E. J.; O'Hagan, D.; Peach, M. J. G.; Slawin, A. M. Z.; Tozer, D. J.; Young, R. J. Angew. Chem., Int. Ed. 2007, 46, 5904-5908. doi:10.1002/anie.200700714

12. Silla, J. M.; Silva, W. G. D. P.; Cormanich, R. A.; Rittner, R.; Tormena, C. F.; Rittner, R.; Freitas, M. P. J. Phys. Chem. A 2014, 118, 503-507. doi:10.1021/jp410458w

13. Silla, J. M.; Duarte, C. J.; Cormanich, R. A.; Rittner, R.; Freitas, M. P. Beilstein J. Org. Chem. 2014, 10, 877-882. doi:10.3762/bjoc.10.84

14. Coelho, J. V.; Freitas, M. P.; Ramalho, T. C. Struct. Chem. 2008, 19, 671-677. doi:10.1007/s11224-008-9348-1

15. Ducati, L. C.; Freitas, M. P.; Tormena, C. F.; Rittner, R. J. Mol. Struct.: THEOCHEM 2008, 851, 147-157. doi:10.1016/j.theochem.2007.11.007

16. Freitas, M. P.; Tormena, C. F.; Garcia, J. C.; Rittner, R.; Abraham, R. J.; Basso, E. A.; Santos, F. P.; Cedran, J. C. J. Phys. Org. Chem. 2003, 16, 833-838. doi:10.1002/poc.664

17. Coelho, J. V.; Freitas, M. P. J. Mol. Struct.: THEOCHEM 2010, 941 , 53-55. doi:10.1016/j.theochem.2009.10.039

18. Yoshinaga, F.; Tormena, C. F.; Freitas, M. P.; Rittner, R.; Abraham, R. J. J. Chem. Soc., Perkin Trans. 2 2002, 1494-1498. doi:10.1039/b204635k

19. Silva, T. F. B.; Andrade, L. A. F.; Silla, J. M.; Duarte, C. J.; Rittner, R.; Freitas, M. P. J. Phys. Chem. A 2014, 118, 6266-6271. doi:10.1021/jp505573x

20. Coelho, J. V.; Freitas, M. P.; Tormena, C. F.; Rittner, R. Magn. Reson. Chem. 2009, 47, 348-351. doi:10.1002/mrc.2385

21. Freitas, M. P.; Bühl, M.; O'Hagan, D. Chem. Commun. 2012, 48, 2433-3435. doi:10.1039/c2cc17180e

22. Silla, J. M.; Freitas, M. P.; Cormanich, R. A.; Rittner, R. J. Org. Chem. 2014, 79, 6385-6388. doi:10.1021/jo501025a

23. Silla, J. M.; Freitas, M. P. J. Fluorine Chem. 2015, 172, 1-6. doi:10.1016/j.jfluchem.2015.01.005

24. Silla, J. M.; Freitas, M. P. RSC Adv. 2016, 6, 74598-74603. doi:10.1039/C6RA10272G

25. Dunitz, J. D.; Taylor, R. Chem. - Eur. J. 1997, 3, 89-98. doi:10.1002/chem.19970030115

26. Cormanich, R. A.; Freitas, M. P.; Tormena, C. F.; Rittner, R. RSC Adv. 2012, 2, 4169-4174. doi:10.1039/c2ra00039c

27. Abraham, R. J.; Bretschneider, E. In Internal Rotation in Molecules; Orville-Thomas, W. J., Ed.; Wiley: London, 1974.

28. Chai, J.-D.; Head-Gordon, M. Phys. Chem. Chem. Phys. 2008, 10, 6615-6620. doi:10.1039/b810189b

29. Frisch, J. M.; Pople, J. A.; Binkley, J. S. J. Chem. Phys. 1984, 80, 3265-3269. doi:10.1063/1.447079
30. Glendening, E. D.; Badenhoop, J. K.; Reed, A. E.; Carpenter, J. E.; Bohmann, J. A.; Morales, C. M.; Landis, C. R.; Weinhold, F. NBO 6.0, Theoretical Chemistry Institute, University of Wisconsin: Madison, 2013; http://nbo6.chem.wisc.edu/.

31. Gaussian 09, Revision D.01; Gaussian, Inc.: Wallingford, CT, 2009.

32. Tomasi, J.; Mennucci, B.; Cammi, R. Chem. Rev. 2005, 105, 2999-3094. doi:10.1021/cr9904009

\section{License and Terms}

This is an Open Access article under the terms of the Creative Commons Attribution License

(http://creativecommons.org/licenses/by/4.0), which permits unrestricted use, distribution, and reproduction in any medium, provided the original work is properly cited.

The license is subject to the Beilstein Journal of Organic Chemistry terms and conditions:

(http://www.beilstein-journals.org/bjoc)

The definitive version of this article is the electronic one which can be found at: doi:10.3762/bjoc. 13.172 